\title{
A Multivariate Regression Model for Predicting the 28days Flexural Strength of Lime-Cement Concrete Beam
}

\author{
${ }^{*}$ Chioma T. G. Awodiji, and Samuel Sule \\ Department of Civil and Environmental Engineering, University of Port-Harcourt, Choba, Nigeria \\ \{chimbaegbulsamvictoryahead\}@yahoo.com \\ ORIGINAL RESEARCH ARTICLE \\ Received: 01-SEP-2021; Reviewed: 10-OCT-2021; Accepted: 13-DEC-2021 \\ http://dx.doi.org/10.46792/fuoyejet.v6i4.692
}

\begin{abstract}
In this study, a multivariate regression model for predicting the 28days flexural strength of lime-cement concrete prototype beam was developed. The response function is a multivariate function of the proportions of the component materials of concrete. A total of twenty mix ratios, consisting of water, Portland cement, hydrated lime, river sand and granite chipping were used in the prediction process. The first ten mix ratios were used for model development while the remaining ten mix ratios were used as check points for model validation. The model developed was tested for adequacy at $95 \%$ level of confidence using the t-statistic. Calculated t-value was -1.3342 and this was less than the critical t-value of 2.2622. Thus, the model was found to be adequate. An average percentage difference of $14.303 \%$ was observed between the model prediction and the experimental values. A visual basic program using the Visual studio 2015 software was developed based on the regression model. It was invoked to quicken the process of selecting the mix ratios of the component materials corresponding to any desired flexural strength value that falls within the region of experimentation and vice versa
\end{abstract}

Keywords- Concrete, flexural strength, multivariate regression model, response function

\section{INTRODUCTION}

A building is said to have collapsed when it no longer satisfies its main function of being safe, comfortable, stable and satisfying to its users (Bamgboye et al., 2019). This happens when it can no longer carry the load it was originally designed to support. The rate of structural failure and collapse of buildings in Nigeria in recent times is worrisome. These unfortunate developments have led to loss of many lives and damages of properties worth millions of dollars. Therefore, there is great need to construct durable and safe buildings (Fapohunda et al., 2020). A review previously conducted reported that materials such as cement, granite, steel, sand concrete and sandcrete blocks play a major role in the stability or collapse of many buildings in Nigeria Bamgboye et al. (2019). They stated that about $10 \%$ to $25 \%$ of all building collapse in Nigeria is as a result of poorquality building materials of which low strength concrete due to improper mix proportioning is a major factor.

The structural failure and the eventual collapse of most buildings may be attributed to improper concrete mixture proportioning (Chendo \& Obi, 2015; Oloyede, Omogun \& Akiniare., 2010). In Nigeria, many on-site construction personnel use mix designs that are not supported by any experimental investigation or current design codes. They sometimes do this to either save cost or make more profit or to increase concrete workability for ease of workmanship. All these adversely affect the structural integrity of the building. Therefore, there is need to proffer and ensure that optimal mix designs for concrete production are achieved and adhered to for various construction needs.

*Corresponding Author

Section E- CIVIL ENGINEERING \& RELATED SCIENCES

Can be cited as:

Awodiji C.T.G. and Sule S. (2021): A Multivariate Regression Model for Predicting the 28days Flexural Strength of Lime-Cement Concrete Beam, FUOYE Journal of Engineering and Technology (FUOYEJET), 6(4), 401-407. http://dx.doi.org/10.46792/fuoyejet.v6i4.692
The increase in demand for cement as a construction material in recent times is worrisome. This is because the more Portland cement is produced, the more the emission of $\mathrm{CO}_{2}$ into the atmosphere. This $\mathrm{CO}_{2}$ found in the earth's atmosphere is causing hotter and hotter temperatures of the globe. Some of the consequences are the loss of sea ice, rise in sea levels, heat waves leading to draught, change in temperature patterns and coastal erosion (NASA, 2021). In addition, a lot of energy is required in the manufacture of Portland cement making the cost of its production very high. This development has denied most Nigerians the opportunity to afford and own their own homes/shelter.

In this study, hydrated lime is introduced into the concrete mix as a partial replacement for Portland cement in order to reduce the cost of concrete production as well as reduce the high energy requirements for the production of Portland cement. In order to achieve excellent mix design of the concrete, a multivariate regression model has been developed to predict the flexural strength of the lime-cement concrete without the need for the classical laboratory experimental approach that is time consuming and labour demanding.

A mathematical model is a description of a system using mathematical concept and languages (Wikipedia, 2021). They are used to describe a system of variables and a set of equations that establishes relationship between the variables. The use of mathematical models in concrete mix design has proven to be successful. They are mathematically rigorous and can be used to define confidence intervals for predictions made. They provide insight into the key factors influencing strength properties of concrete through correlation analysis. Mathematical models evaluated on the basis of test data (experimental readings) are most reliable, accurate and scientific (Wilson, et al., 2019). 
Orie and Osadebe (2015) used the Scheffes mathematical optimization model to predict the flexural strength of mound soil cement blended concrete. They worked on concrete beams of size $150 \mathrm{~mm} \times 150 \mathrm{~mm} \times 750 \mathrm{~mm}$ and developed a program that could predict the mix proportions for the model. Optimum mix ratio generated from their program was 1:1.59:0.46:3.34:0.53 (cement: fine aggregate: coarse aggregate: mound soil: water-cement ratio). This gave a flexural strength of $0.31 \mathrm{~N} / \mathrm{mm}^{2}$. This optimal flexural strength value was compared to the flexural strength of conventional concrete made from mix ratio 1:2:4 (cement: fine aggregate: coarse aggregate) at 28 days. Its value was $1.93 \mathrm{~N} / \mathrm{mm}^{2}$ at 0.5 water-cement ratio. The developed model was seen to be adequate but the mound soil cement blended concrete had flexural strength results that are lower than plain concrete but could still be used for structural purposes.

Dan-asabe et al. (2019), developed mathematical models for predicting the flexural strength, density and water absorption of Doum-palm-kankara clay filler hybrid composite. They used the Design Expert 10.0 software in carrying out their study and observed that the flexural strength data fitted best with the quartic model having an $\mathrm{R}$-square value of $97.6 \%$ and an adjusted $\mathrm{R}^{2}$ value of $93.6 \%$. A number of other scholars have developed mathematical models for different types of unconventional concrete mixture optimization (Anyaogu \& Ezeh, 2013; Ibearugbulem et al. (2013); Ndububa \& Osadebe, 2007; Onwuka \& Sule, 2017; Obam \& Osadebe, 2006). However, their approach for model development is based on predetermined number of mix proportions. The approach used in this study is capable of modeling a set of mixes without predetermining the number of mix proportions.

In this work, mathematical model is developed to predict the flexural strength of hydrated lime-cement concrete beam using a least squares approach. A computer program written in Visual Basic language based on the model developed was invoked to quicken the prediction of the component mix ratios corresponding to the desired flexural strength value and vice versa. The use of hydrated lime as partial replacement for Portland cement as well as the proposed mathematical model for predicting mix ratios will go a long way in reducing the cost of producing cement for construction works and provide an easier and faster means of determining desired flexural strength values and their corresponding mix ratios.

\section{Materials AND Methods \\ 2.1 MATERIALS}

(a) Cement: The cement used as binder for this study is ordinary Portland cement with properties conforming to BS EN 197, Part 1, 2000.

(b) Water: Water for the study was fresh, free of any form of organic matters and potable in nature.

(c) Aggregates: Fine aggregate: The fine aggregate was sharp river sand of nominal size $5 \mathrm{~mm}$. It was obtained from Otamiri River in Imo State and had a bulk density of
$1656.022 \mathrm{~kg} / \mathrm{m}^{3}$. It was washed and sundried for three weeks before it was used for lime-cement concrete prototype beam production. Its bulk density was obtained according to the provisions of BS 882 , part 2, 1992.

(d) Coarse aggregate: The granite chippings of nominal size $20 \mathrm{~mm}$ were as coarse aggregate and obtained in bags from Obinze in Owerri, Imo State. It was properly washed and sundried to remove dirt and had a bulk density of $1706.225 \mathrm{~kg} / \mathrm{m}^{3}$.

(e) Hydrated lime: This was gotten from Okpella in Edo State and conformed to the specification of NIS 444-1 (2003).

\subsubsection{Sample Preparation}

Concrete components include water, Portland cement, hydrated lime; sand and gravel from crushed granite rock were used. Twenty (20) mix ratios were experimented (Awodiji, 2018). The first ten (10) mix ratios were used to formulate the model. While, the remaining ten (10) mix ratios were used to validate the model. Three $150 \mathrm{~mm} x$ $150 \mathrm{~mm} \times 600 \mathrm{~mm}$ prototype beams were produced for each mix ratio to get a total of sixty prototype beams. The beams were cured for twenty-eight days in water at room temperature before being subjected to testing. The mix ratios, corresponding component proportions and their twenty-eight (28) days flexural strength test results are presented in Table 1.

\subsection{MethodS}

The methods used in this study falls under the following classifications:

i. Experimental

ii. Model development

iii. Statistical method

iv. Program development

i. Experimental method: The beam specimen was subjected to flexure using a flexural testing machine in accordance to BS 1881, Part 118 (1983). The third point loading method was adopted and failure loads were determined. These failure loads were then used to obtain the flexural strength for the specimens by applying the formula in equation 1 ;

\section{Flexural strength $\left(\mathrm{N} / \mathrm{mm}^{2}\right)=\mathrm{NL} / \mathrm{bd}^{2}$}

Where $\mathrm{N}$ is the failure load in Newton; $\mathrm{b}$ is the width of the specimen in " $\mathrm{mm}$ "; $\mathrm{d}$ is the depth of the specimen in " $\mathrm{mm}$ " and $\mathrm{L}$ is the length of the specimen in " $\mathrm{mm}$ ".

\section{ii. Development of the multivariate regression model:} The five mixture components are water, cement, hydrated lime, river sand and granite chippings respectively. Let $S$ be the total sum of the component ratios. Then the relative proportion of the ith component in the mixture is given by: 
$x_{i}=s_{i} / S$

$\mathrm{S}=\mathrm{S}_{1}+\mathrm{S}_{2}+\mathrm{S}_{3}+\mathrm{S}_{4}+\mathrm{S}_{5}$

Where $x_{i} \quad i=(1,2,3,4,5)$ are proportions of water, cement, lime, sand and gravel respectively, $s_{1}=$ water, $s_{2}$ = cement, $s_{3}=$ lime, $s_{4}=$ sand, $s_{5}=$ gravel

From equation (2),

$s_{i}=x_{i} * S \quad(\mathrm{i}=1,2,3,4,5)$

Substituting for $\mathrm{Si}$ in equation (3) gives:

$x_{1}+x_{2}+x_{3}+x_{4}+x_{5}+x_{6}=1$

Equation (5) shows that the sum of the component mix ratios is unity.

The quadratic response function for a 5-component concrete mixture can be approximated by;

\section{$Y=\beta_{1} X_{1}+\beta_{2} X_{2}+\beta_{3} X_{3}+\beta_{4} X_{4}+\beta_{5} X_{5}+\beta_{6} X_{1}^{2}+\beta_{7} X_{2}^{2}+\beta_{8} X_{3}^{2}+\beta_{4} X_{4}^{2}+\beta_{10} X_{5}^{2}+\beta_{11} X_{1} X_{2}+\beta_{2} X_{1} X_{3}+\beta_{13} X_{1} X_{4}$ $+\beta_{14} X_{1} X_{5}+\beta_{55} X_{2} X_{3}+\beta_{16} X_{2} X_{4}+\beta_{17} X_{2} X_{5}+\beta_{18} X_{3} X_{4}+\beta_{19} X_{3} X_{5}+\beta_{20} X_{4} X_{5}+e$}

Equation (6) can be written in matrix form as:

$Y=X \beta+E$

Where $E$ is the residual vector associated with the responses at different experimental points, $\beta$ is the vector of the regression coefficients, $X$ is an $n^{*} n$ matrix of mixture component proportions.

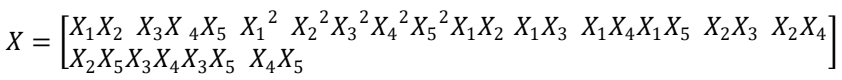

Applying equation (7), the vector of the residuals associated with the responses is given by:

$E=Y-X \beta$

Equation (10) is obtained by taking a norm of equation (9) and then finding the vector of the unknown coefficient, $\beta$ which minimizes equation (9). The norm of equation (9) is given by:

$$
\|\mathrm{E}\|=\|\mathrm{Y}-\mathrm{X} \beta\|
$$

Equation (10) represents the least squares solution of equation (9).

In matrix form, equation (10) is given by:

$\mathrm{E}^{\mathrm{T}} \mathrm{E}=(\mathrm{Y}-\mathrm{X} \beta)^{\mathrm{T} *}(\mathrm{Y}-\mathrm{X} \beta)$

Equation (11) yields:

$E^{\mathrm{T}} \mathrm{E}=\mathrm{Y}^{\mathrm{T}}-2 \beta^{\mathrm{T}} \mathrm{X}^{\mathrm{T}} \mathrm{Y}^{\mathrm{T}}+\beta^{\mathrm{T}} \mathrm{X}^{\mathrm{T}} \mathrm{X} \beta$
The norm of the residual vector $\mathrm{E}$ is made small by differentiating equation (12) with respect to $\beta$ and is given as:

$d\left(E^{\mathrm{T}} \mathrm{E}\right) / \beta=-2 \mathrm{X}^{\mathrm{T}} \mathrm{Y}+2 \mathrm{X}^{\mathrm{T}} \mathrm{X} \beta=0$

It now follows from equation (13) that:

$\beta=\left(X^{\mathrm{T}} X\right)^{-1} X^{\mathrm{T}} \mathrm{Y}$

Equation (14) gives the coefficients $\beta$ that minimizes the residual vector.

Where $\left(\mathrm{X}^{\mathrm{T}} \mathrm{X}\right)^{-1}$ is an inverse of the moment matrix $\left(\mathrm{X}^{\mathrm{T}} \mathrm{X}\right)$.

The moment matrix $\left(\mathrm{X}^{\mathrm{T}} \mathrm{X}\right)$ is obtained by multiplying the transpose of the matrix of the component mix proportions by the matrix of the component mix proportions.

iii. Statistical method: Two statistical methods were adopted in determining the adequacy of the model predictions with respect to experimental results. They are the t-statistics and the percentage error methods. Their equations are respectively given in equations 15 and 16.

$$
\mathrm{T}=\left[\mathrm{DA}^{*}\left(\mathrm{~N}^{1 / 2)}\right] / \mathrm{S}\right.
$$

Where, $\mathrm{DA}=\left(\sum \mathrm{D}_{\mathrm{i}}\right) / \mathrm{N} ; \mathrm{S}=\sum \mathrm{S}^{2 ;} \mathrm{S}^{2}=\sum(\mathrm{DA}-\mathrm{Di})^{2} /(\mathrm{N}-1)$; $\mathrm{Di}=\mathrm{YM}-\mathrm{YE}$

$\mathrm{SE}$ are the experimental responses; $\mathrm{SM}$ are the responses from the model and $\mathrm{N}$ represent the number of responses.

$\%$ error $=\{\mathrm{SE}-\mathrm{SM}) / \mathrm{SE}\} * 100 \%$

iv. Program development: A computer program written in Visual Basic language was developed in order to quicken the prediction of desired flexural strength value and the corresponding mix ratios and vice versa. The program is interactive and can be used to predict the flexural strength of hydrated lime cement concrete beams and their corresponding mix ratios. The development of the program was carried out using the Visual studio 2015 software.

\section{Results AND Discussion}

The mix ratios and their corresponding flexural strength values are presented in Table 1. Mix ratios N1-N10 represent the trial mix ratios used for model development while, mix ratio $\mathrm{C} 1-\mathrm{C} 10$ represent the control mix ratios used for the model validation. The matrix of the component proportions using mix ratios N1-N10 was derived using equation (2), (3) and (8) respectively. 
Table 1. Mix ratios and corresponding 28 days flexural strength values

\begin{tabular}{|c|c|c|c|c|c|c|}
\hline Expt No. & Water & Cement & Lime & Sand & Gravel & $\begin{array}{l}\text { Flexural } \\
\text { strength } \\
\left(\mathrm{N} / \mathrm{mm}^{2}\right)\end{array}$ \\
\hline N1 & 0.6 & 0.9 & 0.1 & 3 & 6 & 2.28 \\
\hline N2 & 0.57 & 0.85 & 0.15 & 2 & 4 & 3.86 \\
\hline N3 & 0.55 & 0.8 & 0.2 & 2.5 & 5 & 3.62 \\
\hline N4 & 0.53 & 0.7 & 0.3 & 1.5 & 3 & 3.49 \\
\hline N5 & 0.5 & 0.6 & 0.4 & 1 & 2 & 2.96 \\
\hline N6 & 0.585 & 0.875 & 0.125 & 2.5 & 5 & 4.37 \\
\hline N7 & 0.575 & 0.85 & 0.15 & 2.75 & 5.5 & 3.91 \\
\hline N8 & 0.565 & 0.8 & 0.2 & 2.25 & 4.5 & 3.98 \\
\hline N9 & 0.55 & 0.75 & 0.25 & 2 & 4 & 3.23 \\
\hline N10 & 0.56 & 0.825 & 0.175 & 2.25 & 4.5 & 4.39 \\
\hline $\mathrm{C} 1$ & 0.55 & 0.775 & 0.225 & 1.75 & 3.5 & 4.26 \\
\hline$C 2$ & 0.535 & 0.725 & 0.275 & 1.5 & 3 & 3.58 \\
\hline $\mathrm{C} 3$ & 0.54 & 0.75 & 0.25 & 2 & 4 & 2.77 \\
\hline $\mathrm{C} 4$ & 0.525 & 0.7 & 0.3 & 1.75 & 3.5 & 2.94 \\
\hline C5 & 0.515 & 0.65 & 0.35 & 1.25 & 2.5 & 2.67 \\
\hline C6 & 0.586 & 0.875 & 0.125 & 2.5 & 5 & 4.51 \\
\hline$C 7$ & 0.575 & 0.85 & 0.15 & 2.75 & 5.55 & 3.27 \\
\hline C8 & 0.55 & 0.775 & 0.225 & 1.75 & 3.55 & 4.02 \\
\hline C9 & 0.525 & 0.7 & 0.3 & 1.75 & 3.55 & 2.82 \\
\hline $\mathrm{C} 10$ & 0.517 & 0.65 & 0.35 & 1.25 & 2.5 & 2.7 \\
\hline
\end{tabular}

The vector of responses of the first ten mix ratios based on Table 1 is given as:

$\mathrm{Y}=\left[\begin{array}{llllllllll}2.28 & 3.86 & 3.62 & 3.49 & 2.96 & 4.37 & 3.91 & 3.98 & 3.23 & 4.39\end{array}\right]$
The matrices of the component proportions $(X)$ and its transpose $\left(X^{\mathrm{T}}\right)$ are given in equation (18) and (19) respectively. The results of moment matrix $\left(X^{T} X\right)$ and moment matrix inverse $\left(\left(X^{T} X\right)^{-1}\right)$ are presented in equation (20) and (21) respectively. The multiplication of matrices $\left(\mathrm{X}^{\mathrm{T}}\right.$ and $\left.\mathrm{X}\right)$ was achieved using 'Mmult' in Microsoft Excel.

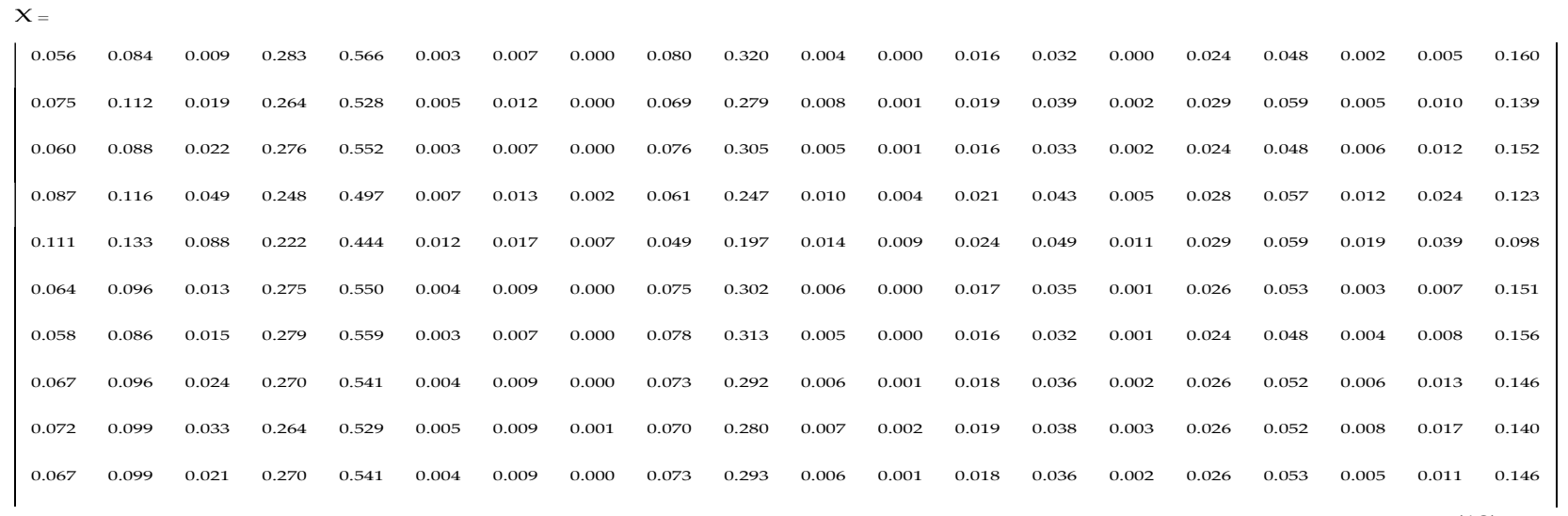

(18)

$X^{\mathrm{T}}=$
\begin{tabular}{|lll}
0.0566 & 0.0753 & 0.0608 \\
0.0849 & 0.1123 & 0.0884 \\
0.0094 & 0.0198 & 0.0221 \\
0.2830 & 0.2642 & 0.2762 \\
0.5660 & 0.5284 & 0.5525 \\
0.0032 & 0.0057 & 0.0037 \\
0.0072 & 0.0126 & 0.0078 \\
0.0001 & 0.0004 & 0.0005 \\
0.0801 & 0.0698 & 0.0763 \\
0.3204 & 0.2792 & 0.3053 \\
0.0048 & 0.0085 & 0.0054 \\
0.0005 & 0.0015 & 0.0013 \\
0.0160 & 0.0199 & 0.0168 \\
0.0320 & 0.0398 & 0.0336 \\
0.0008 & 0.0022 & 0.0020 \\
0.0240 & 0.0297 & 0.0244 \\
0.0481 & 0.0593 & 0.0488 \\
0.0027 & 0.0052 & 0.0061 \\
0.0053 & 0.0105 & 0.0122 \\
0.1602 & 0.1396 & 0.1526
\end{tabular} \mid

0.1111 0.1333 0.0889 0.2222 0.4444 0.0178 0.0079 0.0494 0.0494
0.1975 0.1975
0.0148 0.0148 0.0099
0.0247 0.0494 0.0494 0.0119 0.0296
0.0592 0.0592
0.0198 0.0395 0.0987

0.0644
0.0963
0.0138
0.2752
0.5504
0.0041
0.0093
0.0002
0.0757
0.3029
0.0062
0.0009
0.0177
0.0354
0.0013
0.0265
0.0530
0.0038
0.0076
0.1515

0.0679
0.0962
0.0241
0.2706
0.5412
0.0046
0.0093
0.0006
0.0732
0.2929
0.0065
0.0016
0.0184
0.0367
0.0023
0.0260
0.0521
0.0065
0.0130
0.1464

0.0728
0.0993
0.0331
0.2649
0.5298
0.0053
0.0099
0.0011
0.0702
0.2807
0.0072
0.0024
0.0193
0.0386
0.0033
0.0263
0.0526
0.0088
0.0175
0.1403

0.0674 0.0993 0.0211 0.2708 0.5415 0.0045 0.0099 0.0004 0.0004 0.0733 0.2932 0.0067 0.0014 0.0183
0.0365 0.0365 0.0021 0.0269 0.0538 0.0057 0.0114 0.1466 
$\left(X^{T} X\right)=$

\begin{tabular}{|c|c|c|c|c|c|c|c|c|c|c|c|c|c|c|c|c|c|c|c|}
\hline 0.0547 & 0.0754 & 0.0249 & 0.1893 & 0.3785 & 0.0043 & 0.0081 & 0.0013 & 0.0498 & 0.1993 & 0.0059 & 0.0022 & 0.0141 & 0.0281 & 0.0029 & 0.0195 & 0.0391 & 0.0062 & 0.0123 & 0.0997 \\
\hline 0.0754 & 0.1046 & 0.0330 & 0.2666 & 0.5331 & 0.0059 & 0.0111 & 0.0017 & 0.0705 & 0.2820 & 0.0080 & 0.0029 & 0.0195 & 0.0390 & 0.0037 & 0.0273 & 0.0545 & 0.0082 & 0.0164 & 0.1410 \\
\hline 0.0249 & 0.0330 & 0.0139 & 0.0752 & 0.1504 & 0.0022 & 0.0037 & 0.0009 & 0.0192 & 0.0767 & 0.0029 & 0.0013 & 0.0062 & 0.0123 & 0.0017 & 0.0082 & 0.0164 & 0.0033 & 0.0066 & 0.0383 \\
\hline 0.1893 & 0.2666 & 0.0752 & 0.7083 & 1.4165 & 0.0140 & 0.0273 & 0.0033 & 0.1896 & 0.7583 & 0.0195 & 0.0061 & 0.0499 & 0.0996 & 0.0082 & 0.0705 & 0.1410 & 0.0192 & 0.0383 & 0.3791 \\
\hline 0.3785 & 0.5331 & 0.1504 & 1.4165 & 2.8329 & 0.0281 & 0.0546 & 0.0066 & 0.3791 & 1.5166 & 0.0391 & 0.0123 & 0.0997 & 0.1993 & 0.0165 & 0.1410 & 0.2820 & 0.0384 & 0.0767 & 0.7583 \\
\hline 0.0043 & 0.0059 & 0.0022 & 0.0140 & 0.0281 & 0.0004 & 0.0007 & 0.0001 & 0.0036 & 0.0145 & 0.0005 & 0.0002 & 0.0011 & 0.0022 & 0.0003 & 0.0015 & 0.0030 & 0.0005 & 0.0011 & 0.0073 \\
\hline 0.0081 & 0.0111 & 0.0037 & 0.0273 & 0.0546 & 0.0007 & 0.0012 & 0.0002 & 0.0072 & 0.0286 & 0.0009 & 0.0003 & 0.0021 & 0.0041 & 0.0004 & 0.0029 & 0.0057 & 0.0009 & 0.0018 & 0.0143 \\
\hline 0.0013 & 0.0017 & 0.0009 & 0.0033 & 0.0066 & 0.0001 & 0.0002 & 0.0001 & 0.0008 & 0.0032 & 0.0002 & 0.0001 & 0.0003 & 0.0006 & 0.0001 & 0.0004 & 0.0008 & 0.0002 & 0.0004 & 0.0016 \\
\hline 0.0498 & 0.0705 & 0.0192 & 0.1896 & 0.3791 & 0.0036 & 0.0072 & 0.0008 & 0.0509 & 0.2036 & 0.0051 & 0.0015 & 0.0132 & 0.0264 & 0.0021 & 0.0187 & 0.0375 & 0.0049 & 0.0098 & 0.1018 \\
\hline 0.1993 & 0.2820 & 0.0767 & 0.7583 & 1.5166 & 0.0145 & 0.0286 & 0.0032 & 0.2036 & 0.8146 & 0.0204 & 0.0061 & 0.0528 & 0.1055 & 0.0083 & 0.0749 & 0.1499 & 0.0197 & 0.0394 & 0.4073 \\
\hline 0.0059 & 0.0080 & 0.0029 & 0.0195 & 0.0391 & 0.0005 & 0.0009 & 0.0002 & 0.0051 & 0.0204 & 0.0007 & 0.0003 & 0.0015 & 0.0030 & 0.0003 & 0.0021 & 0.0041 & 0.0007 & 0.0014 & 0.0102 \\
\hline 0.0022 & 0.0029 & 0.0013 & 0.0061 & 0.0123 & 0.0002 & 0.0003 & 0.0001 & 0.0015 & 0.0061 & 0.0003 & 0.0001 & 0.0005 & 0.0011 & 0.0002 & 0.0007 & 0.0014 & 0.0003 & 0.0006 & 0.0031 \\
\hline 0.0141 & 0.0195 & 0.0062 & 0.0499 & 0.0997 & 0.0011 & 0.0021 & 0.0003 & 0.0132 & 0.0528 & 0.0015 & 0.0005 & 0.0037 & 0.0073 & 0.0007 & 0.0051 & 0.0102 & 0.0015 & 0.0031 & 0.0264 \\
\hline 0.0281 & 0.0390 & 0.0123 & 0.0996 & 0.1993 & 0.0022 & 0.0041 & 0.0006 & 0.0264 & 0.1055 & 0.0030 & 0.0011 & 0.0073 & 0.0146 & 0.0014 & 0.0102 & 0.0204 & 0.0031 & 0.0062 & 0.0527 \\
\hline 0.0029 & 0.0037 & 0.0017 & 0.0082 & 0.0165 & 0.0003 & 0.0004 & 0.0001 & 0.0021 & 0.0083 & 0.0003 & 0.0002 & 0.0007 & 0.0014 & 0.0002 & 0.0009 & 0.0018 & 0.0004 & 0.0008 & 0.0041 \\
\hline 0.0195 & 0.0273 & 0.0082 & 0.0705 & 0.1410 & 0.0015 & 0.0029 & 0.0004 & 0.0187 & 0.0749 & 0.0021 & 0.0007 & 0.0051 & 0.0102 & 0.0009 & 0.0071 & 0.0143 & 0.0021 & 0.0041 & 0.0375 \\
\hline 0.0391 & 0.0545 & 0.0164 & 0.1410 & 0.2820 & 0.0030 & 0.0057 & 0.0008 & 0.0375 & 0.1499 & 0.0041 & 0.0014 & 0.0102 & 0.0204 & 0.0018 & 0.0143 & 0.0286 & 0.0041 & 0.0083 & 0.0749 \\
\hline 0.0062 & 0.0082 & 0.0033 & 0.0192 & 0.0384 & 0.0005 & 0.0009 & 0.0002 & 0.0049 & 0.0197 & 0.0007 & 0.0003 & 0.0015 & 0.0031 & 0.0004 & 0.0021 & 0.0041 & 0.0008 & 0.0016 & 0.0099 \\
\hline 0.0123 & 0.0164 & 0.0066 & 0.0383 & 0.0767 & 0.0011 & 0.0018 & 0.0004 & 0.0098 & 0.0394 & 0.0014 & 0.0006 & 0.0031 & 0.0062 & 0.0008 & 0.0041 & 0.0083 & 0.0016 & 0.0032 & 0.0197 \\
\hline 0.0997 & 0.1410 & 0.0383 & 0.3791 & 0.7583 & 0.0073 & 0.0143 & 0.0016 & 0.1018 & 0.4073 & 0.0102 & 0.0031 & 0.0264 & 0.0527 & 0.0041 & 0.0375 & 0.0749 & 0.0099 & 0.0197 & 0.2036 \\
\hline
\end{tabular}

(20)

$\left(X^{\top} X\right)^{-1}=$

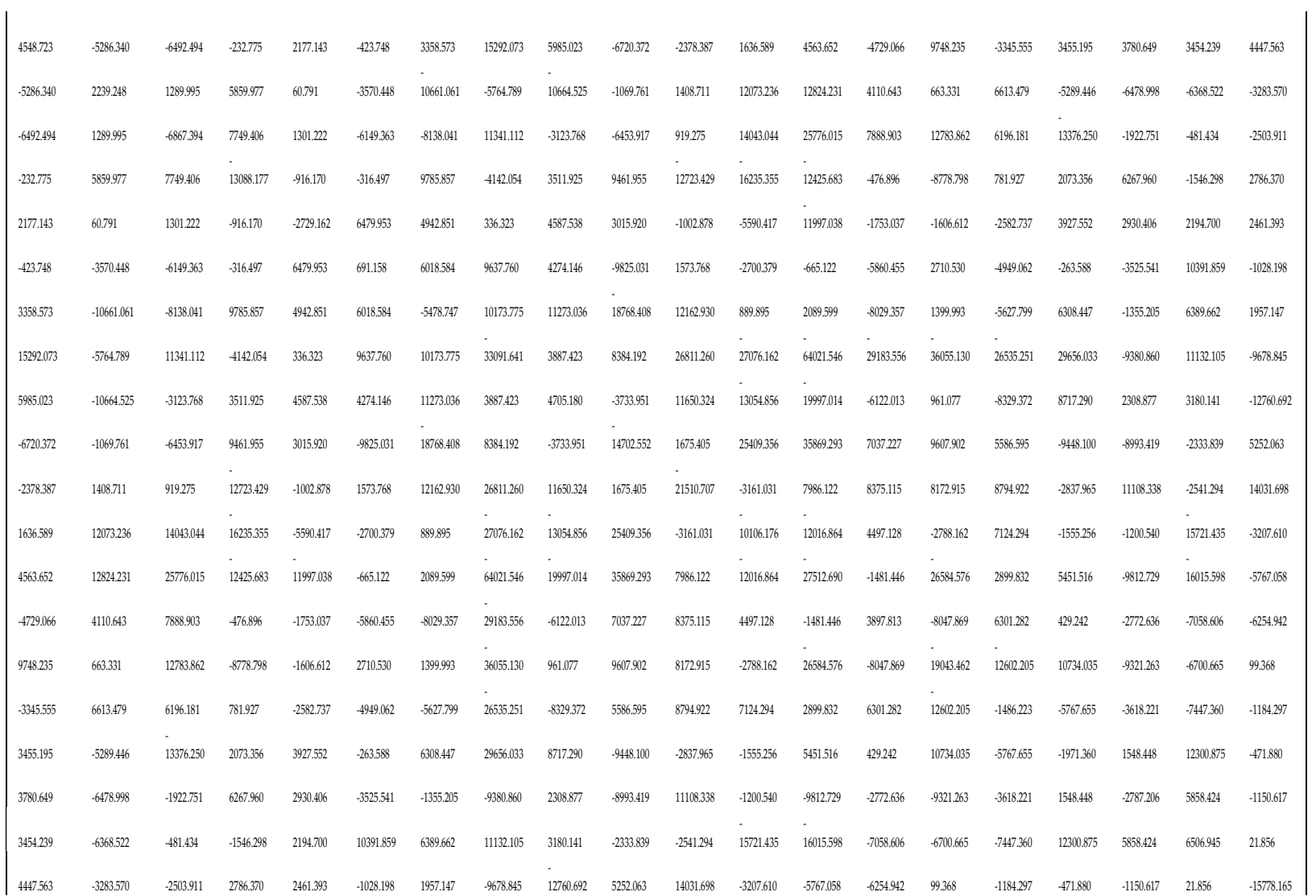


The $X^{T} Y$ vector is obtained by multiplying equation (19) by equation (17) as:

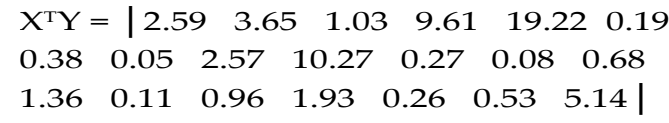

Where $\mathrm{Y}$ vector is given in equation (7)

The coefficient vector $\beta$ is obtained from equation (14) by multiplying equation (21) by equation (22) using 'Mmult' in Microsoft Excel as:

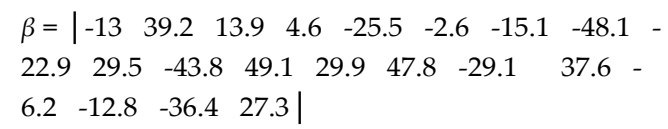

Substituting equation (23) into equation (6) gives the quadratic equation for the flexural strength of the selected mix ratios. This is given as:

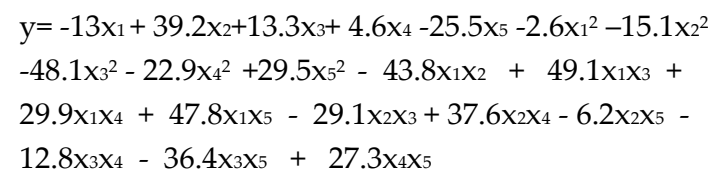

Equation (24) is the mathematical model that predicts the flexural strength of lime-cement concrete for the selected mix ratios based on quadratic response surface.

\subsection{TeSt OF AdEQUACy OF THE NeTWORK}

The observed and predicted values of flexural strength are compared in Table 2 using the percentage error.

Table 2. Comparison of observed and predicted values of flexural strength

\begin{tabular}{cccc}
\hline $\begin{array}{c}\text { Mix } \\
\text { no. }\end{array}$ & $\begin{array}{c}\text { Observed } \\
\text { values }\end{array}$ & $\begin{array}{c}\text { Predicted } \\
\text { values }\end{array}$ & \%Error \\
\hline C1 & 4.26 & 3.849 & 9.65 \\
C2 & 3.58 & 3.709 & 3.60 \\
C3 & 2.77 & 3.469 & 25.23 \\
C4 & 2.94 & 3.304 & 12.38 \\
C5 & 2.67 & 3.323 & 24.46 \\
C6 & 4.51 & 3.862 & 14.37 \\
C7 & 3.27 & 3.558 & 8.81 \\
C8 & 4.02 & 3.833 & 4.65 \\
C9 & 2.82 & 3.294 & 16.81 \\
C10 & 2.7 & 3.323 & 23.07 \\
\hline & & Av. $\%$ & \\
& & error $=$ & 14.303 \\
\hline
\end{tabular}

The results obtained from equation (19) are tested for adequacy at $95 \%$ level of confidence against the control points using t-statistic as shown in Table 3:
Table 3. T-statistic test of flexural strength model based on quadratic function

\begin{tabular}{lll}
\hline & Experiment & Predicted \\
\hline Mean & 3.354 & 3.5524 \\
Variance & 0.4836 & 0.0586 \\
Observations & 10 & 10 \\
Pearson Correlation & 0.9534 & \\
Hypothesized Mean & & \\
Difference & 0 & \\
df & 9 & \\
t Stat & -1.3342 & \\
P(T<=t) one-tail & 0.1075 & \\
t Critical one-tail & 1.8331 & \\
P(T<=t) two-tail & 0.2149 & \\
t Critical two-tail & 2.2622 & \\
Source: Microsoft Excel $(2008)$ &
\end{tabular}

From Table 3, it can be seen that the calculated value of $t$ $(-1.3342)$ is less than the critical $t$-value (2.2622). Hence, the null hypothesis is accepted and the model is adequate and can be used to predict the flexural strength of hydrated lime-cement concrete.

\section{ConCLUSION}

A multivariate regression model has been developed to predict the flexural strength of hydrated lime-cement concrete based on least squares approach. The reliability of the model was investigated at $5 \%$ level of significance using t-statistic and was found to be adequate. A computer program written in Visual Basic was invoked to quicken the prediction of desired flexural strength value and the corresponding mix ratios and vice versa. The Visual Basic program developed is found to be interactive and can be used to predict with reasonable accuracy, the flexural strength of hydrated lime-cement concrete beams and the corresponding mix ratios.

\section{ACKNOWLEDGMENT}

Authors wish to appreciate the Department of Civil Engineering, Federal University of Technology, Owerri for making available their structural laboratory, for the purpose of the study.

\section{REFERENCES}

Anyaogu, L \& Eze, J.C. (2013). Optimization of Compressive Strength of Fly Ash Blended Concrete using Scheffe's Simplex Theory. Natural and Applied Sciences, 4(2), 177-186.

Awodiji, C.T.G. (2018). Investigation of the Structural Characteristics of Lime-Cement Concrete. Published PhD Thesis, Federal University of Technology, Owerri.

Bamgboye. G. O., Ede, A. N., Ngene, B. U., Nwankwo, C., \& Davies, I. (2019). The Role of Construction Materials in Building Collapse. A Review. International Conference on Engineering for Sustainable World. Journal of Physics: Conference series: 1378:0402022. IOP Publishing. Doi: 10.1088/17426596/1378/4/04022.

British Standard Institution. (2000). BS EN 197, Part 1. Composition, Specification and Conformity criteria for common Cements. BSI, London

British Standard Institution. (1992). BS 882, Part 2. Grading Limits for Aggregates. BSI, London

British Standard Institution. (1983). BS 1881:118. Testing Concrete: Method of Determination of Flexural Strength. BSI, London

Chendo, I. J., \& Obi, N. I. (2015). Building Collapse in Nigeria: The 
causes, effects, consequences and remedies. International Journal of Civil Engineering, Construction and Estate Management. 3(4), 4149.

Dan-asabe, B., Yaro, S. A., Yawas, D. S., \& Aku, S. Y. (2019). Statistical Modeling and Optimization of the Flexural Strength, Water Absorption and Density of a Doumplam-Kankara Clay filler Hybrid Composite. Journal of King Saud, University- Engineering $\begin{array}{llll}\text { Science. } & 31(4), & 385-394 . & \text { Doi }\end{array}$ https://doi.org/10.1016/j.ksues.2017.11.0

Fapohunda, C. A., Kilani, A. J., \& Famodimu, B. I. (2020). The Role of State and Professional Bodies in Developing Code for Structural Concrete- Learning from other Nations. FUOYE Journal of Engineering and Technology, 5(1), 130-134.

Ibearugbulem, O. M., Ettu, L. O., Ezeh, J. C., \& Anya, U. C. (2013). A New Regression Model for Optimizing Concrete Mixes. International Journal of Engineering Science and Research Technology. 2(7), 1735-1742.

NASA (2012). Effects/Facts- Climate change: Vital signs of the planet. NASA Climate Change. Retrieved June 10, 2021, from https://climate.nasa.gov>effects.

Ndububa, E. E. \& Osadebe, N. N. (2007). An Optimization of the Flexural Strength of Fibre Cement Mixture using Scheffe's Simplex Lattice. NSE Technical Transaction, 42(1), 1-7.

Nigerian Industrial Standard (2003). NIS 444-1. Composition, Specification and Conformity Criteria for Common Cements. Standard Organization of Nigeria.

Obam, S. O. \& Osadebe, N. N. (2006). Optimization of the Compressive Strength of Rice Husk Ash Pozzolan Concrete. Journal of Scientific and Industrial Studies, 1(2), 51-57.

Oloyede, S. A. Omogun, C. B. \& Akinjare, O. A. (2010). Tracking Causes of Building Collapse in Nigeria. Journal of Sustainable Development, 3(3), 127-132.

Onwuka, D. O. \& Sule, S. (2017). Predicting of Compressive Strength of Chikoko-Cement Concrete using Scheffe's Polynomial Function. Journal of Research Information in Civil Engineering, 14(1), 1338-1358.

Orie, O. U. \& Osadebe, N. N. (2015). Mathematical Model for Prediction of Flexural Strength Chikako of Mound Soil-Cement Blended Concrete. Nigerian Journal of Technology, 34(3), 459-466. Doi: http://dx.doi.org/10.4314/njt.v34i3.5.

Wikipedia. Mathematical Model. Retrieved May 31, 2021 from https://en.wikipedia.org/wiki/Mathematical model.

Wilson, J., Jones, E. \& Dickson, M. (2019). Prediction of Concrete Compressive Strength using Mathematical Regression Model. Concre NZ Conference: Concrete for Life. Holcim NZ Ltd, Christchurch, New Zealand, 1-8. 